\title{
Platinum substituted Cobalt(II, III) Oxide: Interplay of tetrahedral Co(II) sites towards electrochemical oxygen evolution activity
}

Subramanian Nellaiappan ${ }^{\mathrm{a}, \mathrm{b}}{ }^{1}$, Navneet Jhariya $^{\mathrm{c}}{ }^{1}$, Silvia Irusta ${ }^{\mathrm{d}}$, Aditi Singhal ${ }^{\mathrm{c}, *}$

${ }^{a}$ Department of Chemistry, Indian Institute of Technology Gandhinagar, Palaj, Gandhinagar 382355, Gujarat, India

${ }^{b}$ Department of Chemistry, Centre for Nanotechnology \& Advanced Biomaterials (CeNTAB), School of Chemical and Biotechnology, SASTRA Deemed University, Thanjavur 613 401, India ${ }^{\mathrm{c} S}$ School of Engineering and Applied Science (SEAS), Ahmedabad University, Ahmedabad 380009, Gujarat India

${ }^{\mathrm{d}}$ Department of Chemical Engineering, Nanoscience Institute of Aragon (INA), University of Zaragoza, 50018 Zaragoza, Spain

*Corresponding Authors E-mail address: aditi.singhal@ahduni.edu.in (A. Singhal)

1 Both authors have equal contribution

Keywords: Spinel oxide; Pt-subsituted- $\mathrm{Co}_{3} \mathrm{O}_{4}$; Solution combustion; Electrochemistry; Oxygen evolution. 


\begin{abstract}
Substitution of ionic platinum is carried out in $\mathrm{Co}_{3} \mathrm{O}_{4}$ host synthesized by solution combustion strategy. These Pt substituted $\mathrm{Co}_{3} \mathrm{O}_{4}$ spinels characterized by XRD show pure crystalline phase of $\mathrm{Co}_{3} \mathrm{O}_{4}$ without any separated peaks related to $\mathrm{Pt} / \mathrm{PtO}_{\mathrm{x}}$. Electrochemical OER activities of these spinels are investigated by cyclic voltammetry, linear sweep voltammetry and chronoamperometry in neutral, alkaline and neutral buffer electrolytes. LSV studies on $1 \% \mathrm{Pt}$ substituted $\mathrm{Co}_{3} \mathrm{O}_{4}$ exhibit a low overpotential $(\eta)$ of $455 \mathrm{mV}$ at $20 \mathrm{~mA} \mathrm{~cm}{ }^{-2}$ in $\mathrm{KOH}$, as compared to PBS medium. Tafel slope value of $117 \mathrm{mV} \mathrm{dec}^{-1}$ in $\mathrm{KOH}$ represents one electron EC mechanism. The detailed XPS studies indicate that $\mathrm{Pt}$ doping increases the tetrahedral $\mathrm{Co}^{2+}$ sites of $\mathrm{Co}_{3} \mathrm{O}_{4}$. XPS studies before and after the OER also infers that the mixed valence of $\mathrm{Co}$ in the host $\left(\mathrm{Co}_{3} \mathrm{O}_{4}\right)$ undergoes redox $\left(\mathrm{Co}^{2+} / \mathrm{Co}^{3+}\right)$ changes with simultaneous reduction in $\mathrm{Pt}$ dopant from $\mathrm{Pt}^{4+}$ to $\mathrm{Pt}^{2+}$ influencing the OER activity.
\end{abstract}




\section{Introduction}

Spinels give potential applications in broad technical fields such as in semiconductor [1], magnetism [2-5], oxidation [6-10] and catalysis [6, 11-14]. Large class of spinels exist and researchers have worked on Magnesium spinels [2], Zinc Ferrite spinel [4], Nickel based spinels [15], Cuprospinels [16], Iron-Manganese spinels [17] and so on. Particularly, $\mathrm{Co}_{3} \mathrm{O}_{4}$ and its substituted form has been found as an effective electroactive material due to its excellent catalytic activity and corrosion reliability for electrochemical oxygen evolution reaction (OER) in alkaline media $[11,13,18-22]$. Cobalt oxide exists in two distinct forms, $\mathrm{Co}_{3} \mathrm{O}_{4}$ and $\mathrm{CoO} . \mathrm{Co}_{3} \mathrm{O}_{4}$ spinel material exists in cubic close packing array of oxide ions that contains Co(II) ions holding the tetrahedral 8a sites and Co(III) ions in octahedral 16d sites [10, 23]. Both of these oxides show ptype semiconducting behavior but $\mathrm{Co}_{3} \mathrm{O}_{4}$ gives greater conductivity than $\mathrm{CoO}$ [24].

Atomic substitution is referred as one of the significant techniques to gain the desired physicochemical properties [8]. Through the defect for bearance of the spinel structure, it is feasible to substitute a notable fragment of cobalt cations by other metal ion such as $d$-and $f$-block metals [25]. It is found that iron doping improves the activity as catalyst for selective oxidation reactions [8]. Doping of zinc improves the thermal stability of spinel's core structure [26]. Platinum doping has showed positive results for oxidation and electrode modification for efficiency [9, 27]. In a latest research, computational modeling study of water splitting [6] has revealed the role of morphology based activity of cobalt oxide [28] for OER and ORR (oxygen reduction reaction) under varying $\mathrm{pH}$ conditions. However, controversial results still exist regarding its OER performance on size-controllable $\mathrm{Co}_{3} \mathrm{O}_{4}$ hexagonal platelets for determining active sites from two different tetrahedral and octahedral sites using density functional theory (DFT) studies and other characteristic techniques [29]. 
Different synthesis methods have been reported for synthesizing substituted cobalt oxides. He et al. has used the typical oriented aggregation method with binder as water for synthesizing $\mathrm{Co}_{3} \mathrm{O}_{4}$ nanocrystals [30]. Thermal decomposition method has also been adopted for copper substitution in $\mathrm{CoO}_{\mathrm{x}}$ [31]. A facile and surfactant-free synthesis of $3.5-70 \mathrm{~nm}$ size controlled $\mathrm{Co}_{3} \mathrm{O}_{4}$ nanoparticles has been synthesized by altering the ratio of ethanol to water and utilized for the degradation of phenol [12]. Ding et al. followed a two- step procedure for the preparation of $\mathrm{Co}_{3} \mathrm{O}_{4}$ nanofibers by employing electro-spinning on aluminum foil which is followed by calcination $\left(500^{\circ} \mathrm{C}\right.$ for $\left.3 \mathrm{~h}\right)$ and employed as an enzyme-free sensor for glucose detection [32]. Beside these, usual methods of synthesis of spinel oxides are sol-gel [33], homogeneous precipitation [34], solvothermal synthesis [35, 36] and hydrothermal method [3, 37, 38]. Among all, solution-combustion method is used because of its unique reliability and easiness for synthesis of transition metals over spinel oxides [39].

In this paper, different percentages of platinum doping in cobalt oxide $\mathrm{Pt}_{\mathrm{x}} \mathrm{Co}_{3-\mathrm{x}} \mathrm{O}_{4}(\mathrm{x}=$ $0.0075-0.03)$ spinel is achieved using solution-combustion method [40,41]. The aim of this article is (a) how this substitution affects the electrocatalytic OER activity (b) how the OER activity is correlated with the surface chemistry of Co and Pt and (c) plausible mechanism based upon the XPS investigations.

\section{Materials and methods}

\subsection{Materials}

Cobalt (II) nitrate hexahydrate $\left(\mathrm{Co}\left(\mathrm{NO}_{3}\right)_{2} .6 \mathrm{H}_{2} \mathrm{O}\right), 98.05 \%$ pure, from Merck Sp. Pvt. Ltd, Mumbai, India. Hexachloroplatinic acid hexahydrate $\left(\mathrm{H}_{2} \mathrm{PtCl}_{6} 6 \mathrm{H}_{2} \mathrm{O}\right), 99.00 \%$ pure, Pt content 38-40 \% from Sisco Res. Lab, Mumbai, India. Urea $\left(\mathrm{CO}\left(\mathrm{NH}_{2}\right)_{2}\right) 99 \%$ pure Merck Life Sci. Pvt. Ltd. Mumbai, India. All chemicals used for this study were of analytical grade and used without 
further purification. All the solutions and electrolytes were prepared using double distilled Millipore water.

\subsection{Synthesis}

Solution combustion method is one of the efficient and reliable methods for synthesizing the doped metal oxides and pure metal oxides [40, 42, 43]. In this work, Pt-substituted $(0.25 \%$, $0.5 \%$ and $1 \%) \mathrm{Co}_{3} \mathrm{O}_{4}$ spinels were prepared. $\mathrm{Co}_{3-\mathrm{x}} \mathrm{Pt}_{\mathrm{x}} \mathrm{O}_{4}(\mathrm{x}=0.0075-0.03)$ by dissolving $5.0 \mathrm{~g}$ of cobalt nitrate mixed with varying amounts of hexachloroplatinic acid $(8.918,17.9,35.8 \mathrm{mg})$ and varied amounts of urea $(0.680-0.687 \mathrm{~g})$ in a minimal amount of distilled water in a borosilicate glass dish. For $\mathrm{Co}_{3} \mathrm{O}_{4}$ preparation, $2.0 \mathrm{~g}$ of cobalt nitrate is mixed with $0.688 \mathrm{~g}$ of urea. The clear solution containing dish is kept in a muffle furnace at $450^{\circ} \mathrm{C}$. After 30 minutes, the obtained powder is collected in a silica crucible and kept for calcination at $600^{\circ} \mathrm{C}$ overnight (approximately $10 \mathrm{~h})$. After calcination a black color powder is obtained and is used for various analyses. Scheme 1 represents the synthesis procedure for the Pt-substituted- $\mathrm{Co}_{3} \mathrm{O}_{4}$ and undoped pure $\mathrm{Co}_{3} \mathrm{O}_{4}$ catalysts. The synthesized materials were characterized by using the powder X-ray diffraction (XRD, BRUKER D8 DISCOVER diffractometer in the range of $20-80^{\circ}$ ), scanning electron microscopy (FESEM, Jeol, Japan), high-resolution transmission electron microscopy with electron energy disperse spectroscopy (HR-TEM: JSM - 2100, Jeol, Japan) and X-ray photoelectron spectroscopy (XPS, AXIS Ultra DLD spectroscope (Kratos) with a monochromatic Al K $\alpha$ radiation $(1486.6 \mathrm{eV}$, line width $0.8 \mathrm{eV}))$.

\subsection{Electrochemical Studies}

Electrochemical studies were carried out using conventional three-electrode system using an AUTOLAB PGSTAT204 electrochemical workstation at room temperature. The electrolyte solutions were prepared by using double-distilled water. The working electrode was made using 
catalyst ink which is a mixture of $100 \mathrm{mg}$ of the catalyst with $100 \mathrm{mg}$ of 5\% Nafion solution which acts as a binder for ink. Then $650 \mu \mathrm{L}$ of isopropanol was added to make a thin ink, which was then sonicated for $20 \mathrm{~min}$ and then deposited on the glassy carbon (GC) electrode. The geometric area of the working electrode was $0.071 \mathrm{~cm}^{2}$. Cyclic voltammetry $(\mathrm{CV})$ and linear sweep voltammetry (LSV) were carried out using catalyst coated GCE as working electrode, $\mathrm{Ag} / \mathrm{AgCl}$ (sat. $\mathrm{KCl}$ ) as reference electrode and platinum wire as counter electrode. Over potentials $(\eta)$ were calculated by using the equation: $\eta=\mathrm{E}(\mathrm{RHE})-1.23 \mathrm{~V}$ where $\mathrm{E}(\mathrm{RHE})=\mathrm{E}(\mathrm{Ag} / \mathrm{AgCl})+(0.196+0.059 \times \mathrm{pH})$. The electrolytes used in the experiment were, $0.5 \mathrm{M}$ potassium hydroxide solution (KOH; $\mathrm{pH}=13.6), 0.5 \mathrm{M}$ phosphate buffer (PBS; $\mathrm{pH}=7)$ and $0.5 \mathrm{M}$ potassium sulphate solution $\left(\mathrm{K}_{2} \mathrm{SO}_{4}\right.$; $\mathrm{pH}=7$ ). Chronoamperometry study was carried out for 1000 seconds at $1.4 \mathrm{~V}$ in $\mathrm{K}_{2} \mathrm{SO}_{4}$ and $\mathrm{PBS}$ medium and at $0.7 \mathrm{~V}$ in $\mathrm{KOH}$ medium. CV (25 scans) and LSV measurements were carried out at fixed scan rates of $40 \mathrm{mV} \mathrm{s}^{-1}$ and $20 \mathrm{mV} \mathrm{s}^{-1}$ under room temperature. The double layer capacitance is of the order of $13 \mu \mathrm{F} \mathrm{cm}-2$ for both $\mathrm{Co}_{3} \mathrm{O}_{4}$ and $1 \% \mathrm{Pt}$ substituted $\mathrm{Co}_{3} \mathrm{O}_{4}$ confirming the comparable electroactive surface areas.

\section{Results and discussions}

The prepared Pt substituted $\mathrm{Co}_{3} \mathrm{O}_{4}\left(\mathrm{Co}_{3-\mathrm{x}} \mathrm{Pt}_{\mathrm{x}} \mathrm{O}_{4}(\mathrm{x}=0.0075-0.03)\right)$ and pure $\mathrm{Co}_{3} \mathrm{O}_{4}$ catalysts were characterized by XRD (Figure 1a). XRD patterns of Pt-substituted- $\mathrm{CO}_{3} \mathrm{O}_{4}\left(\mathrm{Co}_{3}-\right.$ $\left.{ }_{x} \mathrm{Pt}_{\mathrm{x}} \mathrm{O}_{4}(\mathrm{x}=0.0075-0.03)\right)$ catalysts showed sharp $\mathrm{XRD}$ peaks as seen in the parental $\mathrm{Co}_{3} \mathrm{O}_{4}$ spinel oxide $[40,41]$. No secondary phase or peak related to $\mathrm{Pt} / \mathrm{PtO}_{\mathrm{x}}$ is observed however, complete substitution cannot be ascertained if some segregated phase forms on the surface. Materials appeared to be crystalline and depict large crystallite size. The morphological and microscopy

analysis of $1 \%$ Pt-substituted- $\mathrm{Co}_{3} \mathrm{O}_{4}$ was characterized by SEM (Figure 1b\&c) and HRTEM (Figure 1d-h). As seen in SEM images, 1\% doping concentration of Pt showed well-defined 
particles with hexagonal geometry with very large agglomerates of $1 \%$ Pt-substituted- $\mathrm{Co}_{3} \mathrm{O}_{4}$ (Figure 1b\&c). Morphology is similar to unsubstituted $\mathrm{Co}_{3} \mathrm{O}_{4}$ [40]. Likewise, HRTEM images of $1 \%$ Pt-substituted- $\mathrm{Co}_{3} \mathrm{O}_{4}$ sample showed hexagonal morphology can be seen (Figure $1 \mathrm{~d}$ ) and the particle shape and boundaries are clearly noticeable with pure Co site and Pt-substituted- $\mathrm{Co}_{3} \mathrm{O}_{4}$ (Figure 1e). Size of the particles remain in the range of 60-120 nm and the lattice d-spacing of Pt and Co is $\sim 0.22$ and $\sim 0.46 \mathrm{~nm}$, corresponding to $\operatorname{Pt}\left(\begin{array}{lll}1 & 1 & 1\end{array}\right)$ and $\operatorname{Co}\left(\begin{array}{lll}1 & 1 & 1\end{array}\right)$ [44, 45]. Segregation of $\mathrm{Pt}$ in Pt substituted $\mathrm{Co}_{3} \mathrm{O}_{4}$ explains that complete substitution of $\mathrm{Pt}$ in $\mathrm{Co}_{3} \mathrm{O}_{4}$ could not be achieved. EDS studies confirms the existence of low concentration of Pt $(0.3 \%)$ in the $1 \%$ Pt-substituted$\mathrm{Co}_{3} \mathrm{O}_{4}$ sample (Figure 1h) which means that either there is heterogeneity or irregular distribution of $\mathrm{Pt}$ in the $\mathrm{Co}_{3} \mathrm{O}_{4}$ particles.

Similarly, high resolution XPS spectra of the Co $2 \mathrm{p}$ and Pt $4 \mathrm{f}$ elements of $1 \%$ Pt substituted $\mathrm{Co}_{3} \mathrm{O}_{4}$ catalyst showed the existence of ionic $\mathrm{Pt}^{4+}$ over host $\mathrm{Co}_{3} \mathrm{O}_{4}$ with $\mathrm{Co}^{2+}$ and $\mathrm{Co}^{3+}$ species (Figure 7). The detailed discussion of XPS analysis is available in later section. From the detailed characterizations of the Pt-substituted- $\mathrm{Co}_{3} \mathrm{O}_{4}$, as seen in Scheme 1, one can conclude that ionic Pt (i.e., $\mathrm{Pt}^{4+}$ ) is possibly substituted into the $\mathrm{Co}^{2+}$ (tetrahedral) and $\mathrm{Co}^{3+}$ (octahedral) sites of host $\mathrm{Co}_{3} \mathrm{O}_{4}$. This fact can be confirmed as the substitution of $\mathrm{Pt}^{4+}$ enhances the $\mathrm{Co}^{2+}$ satellite peak at $786.0 \mathrm{eV}$ to maintain the charge balance (Figure 7a, compare lower and middle spectrum)

Cyclic voltammograms (CVs) of $\mathrm{Co}_{3} \mathrm{O}_{4}$ and $\mathrm{Pt}$ substituted $\mathrm{Co}_{3} \mathrm{O}_{4}\left(\mathrm{Co}_{3-\mathrm{x}} \mathrm{Pt}_{\mathrm{x}} \mathrm{O}_{4}\right)$ in $0.5 \mathrm{M}$ $\mathrm{KOH}$ in the potential range of 0.0 to $1.0 \mathrm{~V}$ is shown in Figure $2(\mathrm{a}-\mathrm{d})$. Undoped $\mathrm{Co}_{3} \mathrm{O}_{4}$ shows OER with a current density of $100 \mathrm{~mA} \mathrm{~cm}^{-2}$ (Figure $2 \mathrm{~d}$ ) at 1.0 volts in the first cycle. Noticeable redox features are seen in the $\mathrm{CV}$ at 0.43 and 0.49 volts belonging to $\mathrm{Co}^{2+} / \mathrm{Co}^{3+}$ redox reaction $[40,41]$. OER occurs with an onset potential of $0.6 \mathrm{~V}$. CV of $0.25 \%$ Pt-substituted $\mathrm{Co}_{3} \mathrm{O}_{4}$ also shows cobalt redox peaks at $0.5 \mathrm{~V}$ and $0.42 \mathrm{~V}$ but the current density is suppressed compared to undoped $\mathrm{Co}_{3} \mathrm{O}_{4}$ 
(Figure 2a). This justifies that Pt substitution is possibly on the cobalt site. Apart from this, OER starts occurring with an onset potential of $0.6 \mathrm{~V}$ and reaches a maximum current density of 52.7 $\mathrm{mA} \mathrm{cm}{ }^{-2}$ at $1.0 \mathrm{~V}$. This current is almost half of the $\mathrm{Co}_{3} \mathrm{O}_{4}$ (Figure $2 \mathrm{~d}$ ) thus Pt substitution decreases the activity in this electrolyte. It is possible that Pt substitution is enhancing the non-reactive tetrahedral sites of $\mathrm{Co}^{2+}$ in $\mathrm{Co}_{3} \mathrm{O}_{4}$ to maintain the charge neutrality in the substituted compound [29]. In case of $0.5 \% \mathrm{Pt}$ and $1 \% \mathrm{Pt}$ substitution, the cobalt redox peaks further suppress and the observed maximum current densities at $1.0 \mathrm{~V}$ are $72.3 \mathrm{~mA} \mathrm{~cm}^{-2}$ and $85.3 \mathrm{~mA} \mathrm{~cm}^{-2}$ (Figure $2 \mathrm{~b}, \mathrm{c}$ ). Clearly, the current density is lower compared to $\mathrm{Co}_{3} \mathrm{O}_{4}$ in spite of increase in the Pt concentration. This confirms that the substituted compound indeed has lesser number of active sites than $\mathrm{Co}_{3} \mathrm{O}_{4}$. Increasing trend in the current density among Pt substituted compound is probably due the Pt effect alone.

Likewise, $\mathrm{CV}$ of all synthesized catalysts in $0.5 \mathrm{M} \mathrm{K} \mathrm{K}_{2} \mathrm{SO}_{4}$ at three different positive potential ranges (from 0 to $1.2 \mathrm{~V}, 1.4 \mathrm{~V}$, and $1.6 \mathrm{~V}$ ) was carried out. Since there is no OER activity in the potential range from 0 to $1.2 \mathrm{~V}$, this range was increased up to $1.6 \mathrm{~V}$ to accelerate the catalytic responses as shown in Figure $3(\mathrm{a}-\mathrm{d})$. As seen in the $\mathrm{CV}$, peak appearing between $1.2 \sim 1.6 \mathrm{~V}$ is belonging to $\mathrm{Co}^{2+} / \mathrm{Co}^{3+}$ redox reaction, as in $\mathrm{KOH}$ medium. In case of $\mathrm{Co}_{3} \mathrm{O}_{4}$, OER current density is $14.6 \mathrm{~mA} \mathrm{~cm}^{-2}$ at $1.6 \mathrm{~V}$ at first cycle. $\mathrm{CV}$ appears featureless and no redox features are noticed in this electrolyte medium. Figure $3 \mathrm{a}$ shows the $\mathrm{CV}$ of $0.25 \% \mathrm{Pt}$ substituted $\mathrm{Co}_{3} \mathrm{O}_{4}$. The current density at $1.6 \mathrm{~V}$ is $22.3 \mathrm{~mA} \mathrm{~cm}^{-2}$ at first cycle which is higher than $\mathrm{Co}_{3} \mathrm{O}_{4}$ alone. With $0.5 \% \mathrm{Pt}$ and $1 \%$ Pt substituted $\mathrm{Co}_{3} \mathrm{O}_{4}$ catalysts, $\mathrm{CV}$ appear similar with decrement in current densities. At 1.6 $\mathrm{V}$, the noticed current densities are $20.3 \mathrm{~mA} \mathrm{~cm}^{-2}$ and $17.4 \mathrm{~mA} \mathrm{~cm}^{-2}$ for 0.5 and $1 \%$ Pt substituted $\mathrm{Co}_{3} \mathrm{O}_{4}$ (Figure 3b,c). Thus, lower doping of $\mathrm{Pt}$ in $\mathrm{Co}_{3} \mathrm{O}_{4}$ favors OER in $0.5 \mathrm{M} \mathrm{K}_{2} \mathrm{SO}_{4}$ neutral 
medium and activity decreases with further increases in doping concentration. This again proves that probably ionic $\mathrm{Pt}$ is populating the non-reactive tetrahedral site.

Although both basic and neutral electrolyte medium indicates that Pt doping is not significantly increasing the OER activity, one cannot deny the effect of local $\mathrm{pH}$ change near the electrode. The justification of catalytic behavior can be verified by using a neutral buffer medium for OER activity as the buffer solution will take care of the local $\mathrm{pH}$ effects near the electrode. Thus, the activity will truly reflect the materials property.

$\mathrm{CV}$ experiments in $0.5 \mathrm{M}$ phosphate buffer (PBS) at three different positive potential ranges (from $0.0 \mathrm{~V}$ to $1.2 \mathrm{~V}, 1.4 \mathrm{~V}$ and $1.6 \mathrm{~V}$ ) are shown in Figure 4(a-d). Undoped $\mathrm{Co}_{3} \mathrm{O}_{4}$ (Figure 4d) gives $52.6 \mathrm{~mA} \mathrm{~cm}^{-2}$ at $1.6 \mathrm{~V}$. For $0.25 \%$ Pt-substituted catalyst (Figure $4 \mathrm{a}$ ) the onset potential for OER is found be around $1.1 \mathrm{~V}(1.7 \mathrm{~V}$ vs. RHE) giving $480 \mathrm{mV}$ of over potential. Beyond this range OER activity starts, the current density at $1.2 \mathrm{~V}$ is $6.1 \mathrm{~mA} \mathrm{~cm}^{-2}$, at $1.4 \mathrm{~V}$ is $28.3 \mathrm{~mA} \mathrm{~cm}^{-2}$ and at $1.6 \mathrm{~V}$ is $51.8 \mathrm{~mA} \mathrm{~cm}^{-2}$. The observed current density in $0.5 \mathrm{M}$ PBS at $1.6 \mathrm{~V}$ is similar to undoped $\mathrm{Co}_{3} \mathrm{O}_{4}$ confirming negligible effect of Pt substituent. Likewise, $\mathrm{CV}$ looks similar and OER current densities at $1.6 \mathrm{~V}$ on $0.5 \% \mathrm{Pt}, 1 \% \mathrm{Pt}$ substituted and undoped catalyst $\mathrm{Co}_{3} \mathrm{O}_{4}$ are 52.9 $\mathrm{mA} \mathrm{cm}{ }^{-2}, 50.4 \mathrm{~mA} \mathrm{~cm}^{-2}$ and $52.6 \mathrm{~mA} \mathrm{~cm}^{-2}$ respectively (Figure $4 \mathrm{~b}-\mathrm{d}$ ). Clearly, no catalytic effect is noticed after Pt substitution and with increase in the Pt concentration. Thus, the local $\mathrm{pH}$ effects probably cause the enhancement in current in the case of $\mathrm{KOH}$ and $\mathrm{K}_{2} \mathrm{SO}_{4}$ and the $\mathrm{Pt}$ is mostly inactive.

Usually, steady state responses are more accurate to explain the materials activity compared to potentio-dynamic responses such as CV. Therefore, chronoamperometry studies of OER in $0.5 \mathrm{M} \mathrm{KOH}, 0.5 \mathrm{M} \mathrm{K}_{2} \mathrm{SO}_{4}$ and $0.5 \mathrm{M}$ PBS electrolyte for Pt substituted $(0.25 \%, 0.5 \%$ and $1 \%$ ) and undoped $\mathrm{Co}_{3} \mathrm{O}_{4}$ catalysts are studies and shown in Figure 5. In order to attain the steady 
state current response, the potential is fixed at $0.7 \mathrm{~V}$ for $\mathrm{KOH}$ (Figure $5 \mathrm{a}$ ), $1.4 \mathrm{~V}$ for $\mathrm{K}_{2} \mathrm{SO}_{4}$ and PBS medium (Figure 5b, c) for 1000 seconds. Below this potential, the OER activity was insignificant and at higher potentials, noise appears in the measurement. Corresponding steady state current densities (after 1000 s) as a function of Pt doping concentration are shown in Figure 5d. Clearly, Pt doping only marginally change the current density compared to $\mathrm{Co}_{3} \mathrm{O}_{4}$ alone confirming the inactivity of $\mathrm{Pt}$ in $\mathrm{Co}_{3} \mathrm{O}_{4}$.

In order to further ascertain the true activity trend, LSV experiments and Tafel slope measurements of $1 \%$ Pt-substituted- $\mathrm{Co}_{3} \mathrm{O}_{4}$ have been performed in $\mathrm{KOH}$, PBS and $\mathrm{K}_{2} \mathrm{SO}_{4}$ mediums (Figure 6). From the comparative LSV, the electrochemical activity of 1\% Pt-substituted$\mathrm{Co}_{3} \mathrm{O}_{4}$ for $\mathrm{OER}$ in $\mathrm{KOH}$ medium is highest as compared to $\mathrm{K}_{2} \mathrm{SO}_{4}$ and $\mathrm{PBS}$ medium. The observed overpotential $(\eta)$ on $1 \%$ Pt-substituted- $\mathrm{Co}_{3} \mathrm{O}_{4}$ in $\mathrm{KOH}$ at operationally relevant current density of $20 \mathrm{~mA} \mathrm{~cm}^{-2}$ is $455 \mathrm{mV}$ (Figure 6a) which is lower than that in PBS $(\eta=795 \mathrm{mV})$. The overpotential value is comparable to reported cobalt oxide based materials [46, 47]. The Tafel slope values obtained for $1 \%$ Pt-substituted- $\mathrm{Co}_{3} \mathrm{O}_{4}$ electrode in $\mathrm{KOH}, \mathrm{PBS}$ and $\mathrm{K}_{2} \mathrm{SO}_{4}$ are $117 \mathrm{mV} \mathrm{dec}{ }^{-1}, 153$ $\mathrm{mV} \mathrm{dec}{ }^{-1}, 219 \mathrm{mV} \mathrm{dec}{ }^{-1}$, respectively (Figure 6b). Tafel slope value with $120 \mathrm{mV} \mathrm{dec}{ }^{-1}$ is defined for one electron transfer EC mechanism and is probably in the present case. Likewise, the observed overpotential on pure $\mathrm{Co}_{3} \mathrm{O}_{4}$ at $20 \mathrm{~mA} \mathrm{~cm}^{-2}$ is $467 \mathrm{mV}$ in $\mathrm{KOH}$ and $804 \mathrm{mV}$ in PBS (Figure 6c). It is undetermined for $\mathrm{K}_{2} \mathrm{SO}_{4}$. Respective Tafel slopes on $\mathrm{Co}_{3} \mathrm{O}_{4}$ electrode in $\mathrm{KOH}, \mathrm{PBS}$ and $\mathrm{K}_{2} \mathrm{SO}_{4}$ are $141 \mathrm{mV} \mathrm{dec}^{-1}, 158 \mathrm{mV} \mathrm{dec}{ }^{-1}$, and $295 \mathrm{mV} \mathrm{dec}^{-1}$ (Figure 6d). Both $\mathrm{Co}_{3} \mathrm{O}_{4}$ and $1 \% \mathrm{Pt}$ substituted $\mathrm{Co}_{3} \mathrm{O}_{4}$ show comparable Tafel slope confirming the similarity in the OER mechanism. Further confirmation regarding the rates of OER reaction in $1 \% \mathrm{Pt}$ substituted $\mathrm{Co}_{3} \mathrm{O}_{4}$ and $\mathrm{Co}_{3} \mathrm{O}_{4}$ is evident from the exchange current density $\left(i_{0}\right)$ calculated from the Tafel plots [48, 49]. Calculated $i_{0}$ values on $1 \%$ Pt-substituted- $\mathrm{Co}_{3} \mathrm{O}_{4}$ are $0.63 \mathrm{~mA} \mathrm{~cm}{ }^{-2}, 3.16 \mu \mathrm{A} \mathrm{cm}^{-2}, 1.26 \mu \mathrm{A} \mathrm{cm}^{-2}$ and on pure $\mathrm{Co}_{3} \mathrm{O}_{4}$ are 
$0.39 \mathrm{~mA} \mathrm{~cm}{ }^{-2}, 2.51 \mu \mathrm{A} \mathrm{cm}^{-2}, 7.9 \mu \mathrm{A} \mathrm{cm}{ }^{-2}$ for $\mathrm{KOH}, \mathrm{PBS}$ and $\mathrm{K}_{2} \mathrm{SO}_{4}$ electrolytes, respectively. No specific trend is observed in the exchange current density. In KOH Pt substitution is enhancing the activity while in other solvent is decreases. If we consider PBS free from any $\mathrm{pH}$ change effects, $\mathrm{Co}_{3} \mathrm{O}_{4}$ is more active than $1 \%$ Pt-substituted- $\mathrm{Co}_{3} \mathrm{O}_{4}$. This verifies the fact that $\mathrm{Pt}$ substitution is increasing the non-reactive tetrahedral $\mathrm{Co}^{2+}$ sites.

\section{Evolution of $\mathrm{Pt}$ substituted $\mathrm{Co}_{3} \mathrm{O}_{4}$ surface chemistry}

In order to understand the evolution of surface chemistry of $\mathrm{Pt}$ substituted $\mathrm{Co}_{3} \mathrm{O}_{4}$ catalyst under OER in $0.5 \mathrm{M} \mathrm{KOH}$ condition, pre- and post-OERXPS analysis is analyzed for this study. Our aim is to study the doping effect and mechanism by XPS. XPS is done after chronoamperometry study where scan rate is not relevant. High resolution XPS spectra of the Co $2 \mathrm{p}$ and $\mathrm{Pt} 4 \mathrm{f}$ elements of $1 \% \mathrm{Pt}$ substituted $\mathrm{Co}_{3} \mathrm{O}_{4}$, before and after the electrochemical measurements and $\mathrm{Co} 2 \mathrm{p}$ of pure $\mathrm{Co}_{3} \mathrm{O}_{4}$ catalysts are shown in Figure7. Co $2 \mathrm{p}$ doublets ( $\mathrm{Co} 2 \mathrm{p}_{3 / 2}$ and $\mathrm{Co} 2 \mathrm{p}_{1 / 2}$ ) along with two shakeup satellites are depicted for $\mathrm{Co}_{3} \mathrm{O}_{4}$, pre and post OER analysis of Pt substituted $\mathrm{Co}_{3} \mathrm{O}_{4}$ (Figure 7a). Satellite peak at around $786.0 \mathrm{eV}$ belongs to the presence of $\mathrm{Co}^{2+}$ in the sample [41, 50]. After Pt doping, Co 2p $3 / 2$, shows two prominent peaks at $779.1 \mathrm{eV}$ and $780.6 \mathrm{eV}$ with enhanced shakeup satellite around $786.1 \mathrm{eV}$. This indicates the mixed oxidation states of cobalt and change in the composition of both the states after doping or substitution [41, 50]. Noticeably, the satellite peak at about $786.1 \mathrm{eV}$ become intense after Pt substitution

confirming the enhancement of $\mathrm{Co}^{2+}$ in the system. This happens to maintain the charge balance after $\mathrm{Pt}^{4+}$ insertion in the lattice. Tetrahedral $\mathrm{Co}^{2+}$ is known to be inactive for catalytic reaction, therefore, Pt substitution did not show significant enhancement in the OER activity. XPS spectrum post-OER of Pt-substituted $\mathrm{Co}_{3} \mathrm{O}_{4}$ looks similar to $\mathrm{Co}_{3} \mathrm{O}_{4}$ with suppressed satellite at $786.0 \mathrm{eV}$. 
This may indicate that $\mathrm{Pt}$ is possibly coming out of the $\mathrm{Co}_{3} \mathrm{O}_{4}$ matrix. Thus, Pt substituted $\mathrm{Co}_{3} \mathrm{O}_{4}$ is unstable under positive applied potential.

In case of Pt (dopant) before OER, the Pt 4f core level XPS spectra showed two doublets of $\mathrm{Pt} 4 \mathrm{f}_{7 / 2}$ and $\mathrm{Pt} 4 \mathrm{f}_{5 / 2}$ peaks at 74.4 and $77.8 \mathrm{eV}$ (Figure $7 \mathrm{~b}$ ). The deconvolution of $\mathrm{Pt} 4 \mathrm{f}_{7 / 2}$ suggests that the dopant Pt majorly exist in +4 oxidation state $[51,52]$. Evidently, the formation of more $\mathrm{Co}^{2+}$ after $\mathrm{Pt}^{4+}$ substitution is to maintain the charge neutrality because higher valent $\mathrm{Pt}$ is replacing lower valent Co. XPS of Pt 4f post-OER is quite noisy and fitting is a challenge. With the best of our ability we tried to deconvoluted and the deconvoluted $\mathrm{Pt} 4 \mathrm{f}_{7 / 2}$ spectrum shows the formation of more $\mathrm{Pt}^{2+}$ at $72.4 \mathrm{eV}$ and $75.7 \mathrm{eV}$ [51]. This appears strange as $\mathrm{Pt}$ is expected to remain oxidized under positive applied potential [53]. The fact that $\mathrm{Co}^{2+}$ in the $\mathrm{Pt}$ substituted sample, again converts to $\mathrm{Co}^{3+}$ after OER (Figure 7a) probably causing the $\mathrm{Pt}^{4+}$ to get reduced and hence it comes out to the surface of $\mathrm{Co}_{3} \mathrm{O}_{4}$. During OER activity, the formation of +2 oxidation state of Pt infers the adsorption of hydroxyl group $\left(\mathrm{Pt}^{2+}(\mathrm{OH})_{\mathrm{ads}}\right)$ over Pt surface [51]. Considering mixed valence states of $\mathrm{Co}$ and $\mathrm{Pt}$ ions of spinel $\mathrm{Pt}$ substituted $\mathrm{Co}_{3} \mathrm{O}_{4}$ oxide, OER mechanism can be explained as follows:

$\mathrm{Co}_{2-2 y}^{3+} \mathrm{Co}_{1+y}^{2+} \mathrm{Pt}_{y}^{4+} \mathrm{O}_{4}+2(\mathrm{OH})^{-} \rightarrow \mathrm{Co}_{2-2 y+\delta}^{3+} \mathrm{Co}_{1-\delta}^{2+} \mathrm{Pt}_{y-\delta^{\prime}}^{4+} \mathrm{Pt}_{\delta^{\prime}}^{2+} \mathrm{O}_{4}+\mathrm{O}_{2} \uparrow+2 \mathrm{H}^{+}+2 \bar{e}$

The overall electrochemical activity of spinel Pt-substituted $\mathrm{Co}_{3} \mathrm{O}_{4}$ oxide can be explained by considering that mixed valence Co undergoes redox changes between $\mathrm{Co}^{2+}$ and $\mathrm{Co}^{3+}$ in agreement with the XPS spectra of Co $2 \mathrm{p}_{3 / 2}$. Formation of $\mathrm{Pt}^{2+}$ from $\mathrm{Pt}^{4+}$ oxidation state (Figure $7 b$ ) is due to the formation of $\mathrm{Co}^{3+}$ from $\mathrm{Co}^{2+}$ causing some $\mathrm{Pt}^{4+}$ to get reduced. At this stage $\mathrm{Pt}^{2+}$ comes out of the $\mathrm{Co}_{3} \mathrm{O}_{4}$. From this, we can conclude that the interplay of octahedral sites $\left(\mathrm{Co}^{3+}\right)$ and tetrahedral $\left(\mathrm{Co}^{2+}\right)$ along with ionic Pt affects the OER activity. Schematic representation for the surface evolution of the Pt-substituted- $\mathrm{Co}_{3} \mathrm{O}_{4}$ before and after electrochemical treatment 
(Scheme 1) and the substitution of ionic Pt (i.e., $\left.\mathrm{Pt}^{4+}\right)$ into the tetrahedral $\left(\mathrm{Co}^{2+}\right)$ and octahedral $\left(\mathrm{Co}^{3+}\right)$ sites of host $\mathrm{Co}_{3} \mathrm{O}_{4}$ which assured the formation of more tetrahedral $\mathrm{Co}^{2+}$ sites, $\mathrm{Pt}$ substituted $\mathrm{Co}_{3} \mathrm{O}_{4}$ is only marginally superior to unsubstituted $\mathrm{Co}_{3} \mathrm{O}_{4}$.

\section{Conclusion}

Highly crystalline, platinum substituted cobalt oxide $\left(\mathrm{Co}_{3-\mathrm{x}} \mathrm{Pt}_{\mathrm{x}} \mathrm{O}_{4}(\mathrm{x}=0.0075-0.03)\right)$ spinel oxides has been synthesized by solution combustion method. Electrochemical OER is performed using these spinel oxides in $\mathrm{KOH}, \mathrm{K}_{2} \mathrm{SO}_{4}$, and phosphate buffer medium. $\mathrm{CV}$ and chronoamperometric studies have indicated that only marginal or no improvement is noticed in the Pt substituted compound compared to $\mathrm{Co}_{3} \mathrm{O}_{4}$. This is attributed to the formation of more tetrahedral $\mathrm{Co}^{2+}$ after $\mathrm{Pt}^{4+}$ substitution. XPS studies confirmed this phenomenon. LSV experiments infer that the OER overpotential of $1 \%$ Pt-substituted- $\mathrm{Co}_{3} \mathrm{O}_{4}$ and pure $\mathrm{Co}_{3} \mathrm{O}_{4}$ at the current density of $20 \mathrm{~mA}$ $\mathrm{cm}^{-2}$ in $\mathrm{KOH}$ medium are $455 \mathrm{mV}$ and $467 \mathrm{mV}$ as compared to PBS $(\eta=795 \mathrm{mV}$ for $1 \%$ Ptsubstituted $\mathrm{Co}_{3} \mathrm{O}_{4}$ and $\eta=804 \mathrm{mV}$ pure $\mathrm{Co}_{3} \mathrm{O}_{4}$ ). Tafel slope indicates one electron transfer EC mechanism in $\mathrm{KOH}$ and PBS. Exchange current density $\left(i_{0}\right)$ values on $1 \%$ Pt-substituted $\mathrm{Co}_{3} \mathrm{O}_{4}$ are $0.63 \mathrm{~mA} \mathrm{~cm}^{-2}(\mathrm{KOH}), 3.16 \mu \mathrm{A} \mathrm{cm}^{-2}(\mathrm{PBS})$ and $1.26 \mu \mathrm{A} \mathrm{cm}^{-2}\left(\mathrm{~K}_{2} \mathrm{SO}_{4}\right)$. No set trend in the activity is observed in the Pt substituted $\mathrm{Co}_{3} \mathrm{O}_{4}$ in comparison to $\mathrm{Co}_{3} \mathrm{O}_{4}$. Activity after Pt substitution decreases in regards to the exchange current density. This demonstrates that Pt substitution increases the tetrahedral $\mathrm{Co}^{2+}$ sites which do not impart any activity to the substituted compound. Detailed XPS studies indicate that during OER, mixed valence of Co in the host $\left(\mathrm{Co}_{3} \mathrm{O}_{4}\right)$ undergoes redox changes involving $\mathrm{Co}^{2+}$ and $\mathrm{Co}^{3+}$ influencing the $\mathrm{Pt}^{4+}$ reduction to $\mathrm{Pt}^{2+}$ species. If one can find a suitable dopant which populates the active octahedral sites of $\mathrm{Co}_{3} \mathrm{O}_{4}$, activity improvement is expected. For example, $\mathrm{Ni}$ substituted $\mathrm{Co}_{3} \mathrm{O}_{4}$ has been shown to improve the OER activity of parent $\mathrm{Co}_{3} \mathrm{O}_{4}$. 


\section{Acknowledgments}

A.S. acknowledges Ahmedabad University and funding support from Department of Science and Technology-SERB sponsored research project (DST SERB-EMR/2016/ 005565) for funding and fellowship. Prof. Sudhanshu Sharma from IIT Gandhinagar is gratefully acknowledged for useful discussion.

\section{Author contributions}

A.S. envisaged the idea and S.N. executed the experiments and wrote the manuscript. N.J. synthesized and characterized the materials. S.I. carried out XPS measurements. All the authors contributed to the data analysis and writing and gave approval for the final submission.

\section{Notes}

The authors declare no competing financial interest.

\section{References}

[1] S. Venkatraman, A. Manthiram, Synthesis and Characterization of P3-Type CoO2- $\delta$, Chemistry of Materials, 14 (2002) 3907-3912.

[2] P. Canepa, S.-H. Bo, G. Sai Gautam, B. Key, W.D. Richards, T. Shi, Y. Tian, Y. Wang, J. Li, G. Ceder, High magnesium mobility in ternary spinel chalcogenides, Nature Communications, 8 (2017) 1759.

[3] G. Wang, X. Shen, J. Horvat, B. Wang, H. Liu, D. Wexler, J. Yao, Hydrothermal Synthesis and Optical, Magnetic, and Supercapacitance Properties of Nanoporous Cobalt Oxide Nanorods, The Journal of Physical Chemistry C, 113 (2009) 4357-4361.

[4] A. Meidanchi, O. Akhavan, Superparamagnetic zinc ferrite spinel-graphene nanostructures for fast wastewater purification, Carbon, 69 (2014) 230-238. 
[5] C. Pan, Y.J. Lee, B. Ammundsen, C.P. Grey, 6Li MAS NMR Studies of the Local Structure and Electrochemical Properties of Cr-doped Lithium Manganese and Lithium Cobalt Oxide Cathode Materials for Lithium-Ion Batteries, Chemistry of Materials, 14 (2002) 2289-2299.

[6] M. Schilling, S. Luber, Computational Modeling of Cobalt-Based Water Oxidation: Current Status and Future Challenges, Frontiers in Chemistry, 6 (2018).

[7] C.K. Kim, Internally oxidized cobalt-rich amorphous alloys for potential magnetic recording media application, Materials Science and Engineering: B, 40 (1996) 72-79.

[8] N. Bahlawane, P.H.T. Ngamou, V. Vannier, T. Kottke, J. Heberle, K. Kohse-Höinghaus, Tailoring the properties and the reactivity of the spinel cobalt oxide, Physical Chemistry Chemical Physics, 11 (2009) 9224-9232.

[9] H. Liu, C. Li, D. Chen, P. Cui, F. Ye, J. Yang, Uniformly dispersed platinum-cobalt alloy nanoparticles with stable compositions on carbon substrates for methanol oxidation reaction, Scientific Reports, 7 (2017) 11421.

[10] Z.P. Xu, H.C. Zeng, Control of Surface Area and Porosity of Co3O4 via Intercalation of Oxidative or Nonoxidative Anions in Hydrotalcite-like Precursors, Chemistry of Materials, 12 (2000) 3459-3465.

[11] B. Cui, H. Lin, J.-B. Li, X. Li, J. Yang, J. Tao, Core-Ring Structured NiCo2O4 Nanoplatelets: Synthesis, Characterization, and Electrocatalytic Applications, Advanced Functional Materials, 18 (2008) 1440-1447.

[12] Y. Dong, K. He, L. Yin, A. Zhang, A facile route to controlled synthesis of Co3O4nanoparticles and their environmental catalytic properties, Nanotechnology, 18 (2007) 435602.

[13] F. Jiao, H. Frei, Nanostructured Cobalt Oxide Clusters in Mesoporous Silica as Efficient Oxygen-Evolving Catalysts, Angewandte Chemie International Edition, 48 (2009) 18411844.

[14] J. Cho, Y.J. Kim, T.-J. Kim, B. Park, Zero-Strain Intercalation Cathode for Rechargeable LiIon Cell, Angewandte Chemie International Edition, 40 (2001) 3367-3369.

[15] K. Shih, J.O. Leckie, Nickel aluminate spinel formation during sintering of simulated Niladen sludge and kaolinite, Journal of the European Ceramic Society, 27 (2007) 91-99. 
[16] C.-Y. Hu, K. Shih, J.O. Leckie, Formation of copper aluminate spinel and cuprous aluminate delafossite to thermally stabilize simulated copper-laden sludge, Journal of Hazardous Materials, 181 (2010) 399-404.

[17] G.D. Rieck, F.C.M. Driessens, The structure of manganese-iron-oxygen spinels, Acta Crystallographica, 20 (1966) 521-525.

[18] X. Wu, K. Scott, CuxCo3-xO4 $(0 \leq \mathrm{x}<1)$ nanoparticles for oxygen evolution in high performance alkaline exchange membrane water electrolysers, Journal of Materials Chemistry, 21 (2011) 12344-12351.

[19] I. Nikolov, R. Darkaoui, E. Zhecheva, R. Stoyanova, N. Dimitrov, T. Vitanov, Electrocatalytic activity of spinel related cobalties $\mathrm{MxCo} 3-\mathrm{xO} 4(\mathrm{M}=\mathrm{Li}, \mathrm{Ni}, \mathrm{Cu})$ in the oxygen evolution reaction, Journal of Electroanalytical Chemistry, 429 (1997) 157-168.

[20] B. Lu, D. Cao, P. Wang, G. Wang, Y. Gao, Oxygen evolution reaction on Ni-substituted Co3O4 nanowire array electrodes, International Journal of Hydrogen Energy, 36 (2011) 7278.

[21] B.S. Yeo, A.T. Bell, Enhanced Activity of Gold-Supported Cobalt Oxide for the Electrochemical Evolution of Oxygen, Journal of the American Chemical Society, 133 (2011) 5587-5593.

[22] Y. Li, P. Hasin, Y. Wu, NixCo3-xO4 Nanowire Arrays for Electrocatalytic Oxygen Evolution, Advanced Materials, 22 (2010) 1926-1929.

[23] A.F. Wells, Structural inorganic chemistry, Clarendon Press, Oxford, 1975.

[24] Semiconductor Nanoparticles, in: Z.L. Wang, Y. Liu, Z. Zhang (Eds.) Handbook of Nanophase and Nanostructured Materials, Springer US, Boston, MA, 2003, pp. 813-848.

[25] N.W. Grimes, The spinels: versatile materials, Physics in Technology, 6 (1975) 22-27.

[26] N. Bahlawane*, P.A. Premkumar, J. Feldmann, K. Kohse-Höinghaus, Preparation of Doped Spinel Cobalt Oxide Thin Films and Evaluation of their Thermal Stability, Chemical Vapor Deposition, 13 (2007) 118-122.

[27] B.P. Vinayan, R. Nagar, N. Rajalakshmi, S. Ramaprabhu, Novel Platinum-Cobalt Alloy Nanoparticles Dispersed on Nitrogen-Doped Graphene as a Cathode Electrocatalyst for PEMFC Applications, Advanced Functional Materials, 22 (2012) 3519-3526.

[28] P.W. Menezes, A. Indra, D. González-Flores, N.R. Sahraie, I. Zaharieva, M. Schwarze, P. Strasser, H. Dau, M. Driess, High-Performance Oxygen Redox Catalysis with Multifunctional 
Cobalt Oxide Nanochains: Morphology-Dependent Activity, ACS Catalysis, 5 (2015) 20172027.

[29] Y. Xu, F. Zhang, T. Sheng, T. Ye, D. Yi, Y. Yang, S. Liu, X. Wang, J. Yao, Clarifying the controversial catalytic active sites of $\mathrm{Co}_{3} \mathrm{O}_{4}$ for the oxygen evolution reaction, J. Mater. Chem. A, 7 (2019) 23191-23198.

[30] T. He, D. Chen, X. Jiao, Controlled Synthesis of Co3O4 Nanoparticles through Oriented Aggregation, Chemistry of Materials, 16 (2004) 737-743.

[31] A. La Rosa-Toro, R. Berenguer, C. Quijada, F. Montilla, E. Morallón, J.L. Vázquez, Preparation and Characterization of Copper-Doped Cobalt Oxide Electrodes, The Journal of Physical Chemistry B, 110 (2006) 24021-24029.

[32] Y. Ding, Y. Wang, L. Su, M. Bellagamba, H. Zhang, Y. Lei, Electrospun Co3O4 nanofibers for sensitive and selective glucose detection, Biosensors and Bioelectronics, 26 (2010) 542548.

[33] F. Švegl, B. Orel, I. Grabec-Švegl, V. Kaučič, Characterization of spinel Co3O4 and Li-doped $\mathrm{Co} 3 \mathrm{O} 4$ thin film electrocatalysts prepared by the sol-gel route, Electrochimica Acta, 45 (2000) 4359-4371.

[34] R. Xu, H.C. Zeng, Dimensional Control of Cobalt-hydroxide-carbonate Nanorods and Their Thermal Conversion to One-Dimensional Arrays of Co3O4 Nanoparticles, The Journal of Physical Chemistry B, 107 (2003) 12643-12649.

[35] X. Wang, X. Chen, L. Gao, H. Zheng, Z. Zhang, Y. Qian, One-Dimensional Arrays of Co3O4 Nanoparticles: Synthesis, Characterization, and Optical and Electrochemical Properties, The Journal of Physical Chemistry B, 108 (2004) 16401-16404.

[36] J.W. Schultze, Sergio Trasatti (Ed.): Electrodes of Conductive Metallic Oxides, Part A. Elsevier Scientific Publishing Company, Amsterdam, New York 1980. Preis: 83.00 US \$, 170.00 Dfl, Berichte der Bunsengesellschaft für physikalische Chemie, 85 (1981) 461-462.

[37] M.M. Rahman, A. Jamal, S.B. Khan, M. Faisal, Fabrication of Highly Sensitive Ethanol Chemical Sensor Based on Sm-Doped Co3O4 Nanokernels by a Hydrothermal Method, The Journal of Physical Chemistry C, 115 (2011) 9503-9510.

[38] Y. Yao, Z. Yang, H. Sun, S. Wang, Hydrothermal Synthesis of Co3O4-Graphene for Heterogeneous Activation of Peroxymonosulfate for Decomposition of Phenol, Industrial \& Engineering Chemistry Research, 51 (2012) 14958-14965. 
[39] A. Varma, A.S. Mukasyan, A.S. Rogachev, K.V. Manukyan, Solution Combustion Synthesis of Nanoscale Materials, Chemical Reviews, 116 (2016) 14493-14586.

[40] A. Singhal, A. Bisht, A. Kumar, S. Sharma, One pot, rapid synthesis of $\mathrm{Co}_{3} \mathrm{O}_{4}$ by solution combustion method and its electrochemical properties in different electrolytes, Journal of Electroanalytical Chemistry, 776 (2016) 152-161.

[41] A. Singhal, A. Bisht, S. Irusta, Enhanced oxygen evolution activity of $\mathrm{Co}_{3-\mathrm{x}} \mathrm{Ni}_{\mathrm{x}} \mathrm{O}_{4}$ compared to $\mathrm{Co}_{3} \mathrm{O}_{4}$ by low Ni doping, Journal of Electroanalytical Chemistry 823 (2018) 482-491.

[42] M.S. Hegde, G. Madras, K.C. Patil, Noble Metal Ionic Catalysts, Accounts of Chemical Research, 42 (2009) 704-712.

[43] A. Varma, A.S. Mukasyan, A.S. Rogachev, K.V. Manukyan, Solution Combustion Synthesis of Nanoscale Materials, Chemical Reviews,, 116 (2016) 14493-14586.

[44] Y. Zhao, S. Chen, B. Sun, D. Su, X. Huang, H. Liu, Y. Yan, K. Sun, G. Wang, Graphene$\mathrm{Co} 3 \mathrm{O} 4$ nanocomposite as electrocatalyst with high performance for oxygen evolution reaction, Scientific Reports, 5 (2015) 7629.

[45] P. Wu, H. Lv, T. Peng, D. He, S. Mu, Nano conductive ceramic wedged graphene composites as highly efficient metal supports for oxygen reduction, Scientific Reports, 4 (2014) 3968.

[46] Y. Wang, T. Zhou, K. Jiang, P. Da, Z. Peng, J. Tang, B. Kong, W.B. Cai, Z. Yang, G. Zhen, Reduced Mesoporous $\mathrm{Co}_{3} \mathrm{O}_{4}$ Nanowires as Efficient Water Oxidation Electrocatalysts and Supercapacitor Electrodes Advance Energy Materials, 4 (2014) 1400696-1400701.

[47] S. Mao, Z. Wen, T. Huang, Y. Hou, J. Chen, High-performance bi-functional electrocatalysts of 3D crumpled graphene-cobalt oxide nanohybrids for oxygen reduction and evolution reactions, Energy and Environmental Science, 7 (2014) 609-616.

[48] Y.-C. Liu, J.A. Koza, J.A. Switzer, Conversion of electrodeposited $\mathrm{Co}(\mathrm{OH})_{2}$ to $\mathrm{CoOOH}$ and $\mathrm{Co}_{3} \mathrm{O}_{4}$, and comparison of their catalytic activity for the oxygen evolution reaction, Electrochimica Acta 140 (2014) 359-365.

[49] A.J. Bard, L.R. Faulkner, Electrochemical Methods: Fundamental and Applications, JohnWiley \& Sons, New York1980.

[50] X. Ma, W. Zhang, Y. Deng, C. Zhong, W. Hu, X. Han, Phase and composition controlled synthesis of cobalt sulfide hollow nanospheres for electrocatalytic water splitting, Nanoscale 10 (2018) 4816-4824. 
[51] M. Favaro, C. Valero-Vidal, J. Eichhorn, F.M. Toma, P.N. Ross, J. Yano, Z. Liu, E. J. Crumlin, Elucidating the alkaline oxygen evolution reaction mechanism on platinum, Journal of Material Chemistry A, 5 (2017) 11634-11643.

[52] A. Bisht, P. Zhang, C. Shivakumara, S. Sharma, Pt-doped and Pt-supported $\mathrm{La}_{1-\mathrm{x}} \mathrm{Sr}_{\mathrm{x}} \mathrm{CoO}_{3}$ : Comparative activity of $\mathrm{Pt}^{4+}$ and $\mathrm{Pt}^{0}$ toward the $\mathrm{CO}$ poisoning effect in formic acid and methanol electro-oxidation, Journal of Physical Chemistry C, 119 (2015) 14126-14134.

[53] S. Sharma, M.S. Hegde, Pt metal- $\mathrm{CeO}_{2}$ interaction: Direct observation of redox coupling between $\mathrm{Pt}^{0} / \mathrm{Pt}^{2+} / \mathrm{Pt}^{4+}$ and $\mathrm{Ce}^{4+} / \mathrm{Ce}^{3+}$ states in $\mathrm{Ce}_{0.98} \mathrm{Pt}_{0.02} \mathrm{O}_{2-\delta}$ catalyst by a combined electrochemical and x-ray photoelectron spectroscopy study, The Journal of Chemical Physics, 130 (2009) 114706-114717. 


\section{Scheme 1}

\section{Synthesis of Platinum substituted Cobalt (II, III) oxide catalyst:}
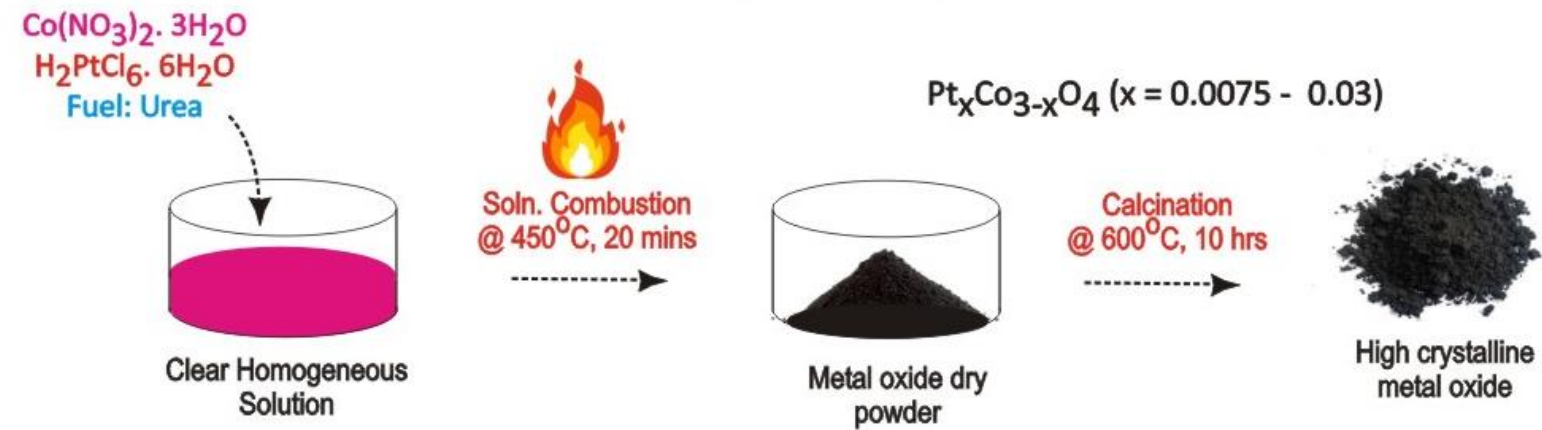

\section{Evolution of Pt substituted $\mathrm{CO}_{3} \mathrm{O}_{4}$ spinel surface chemistry towards OER:}

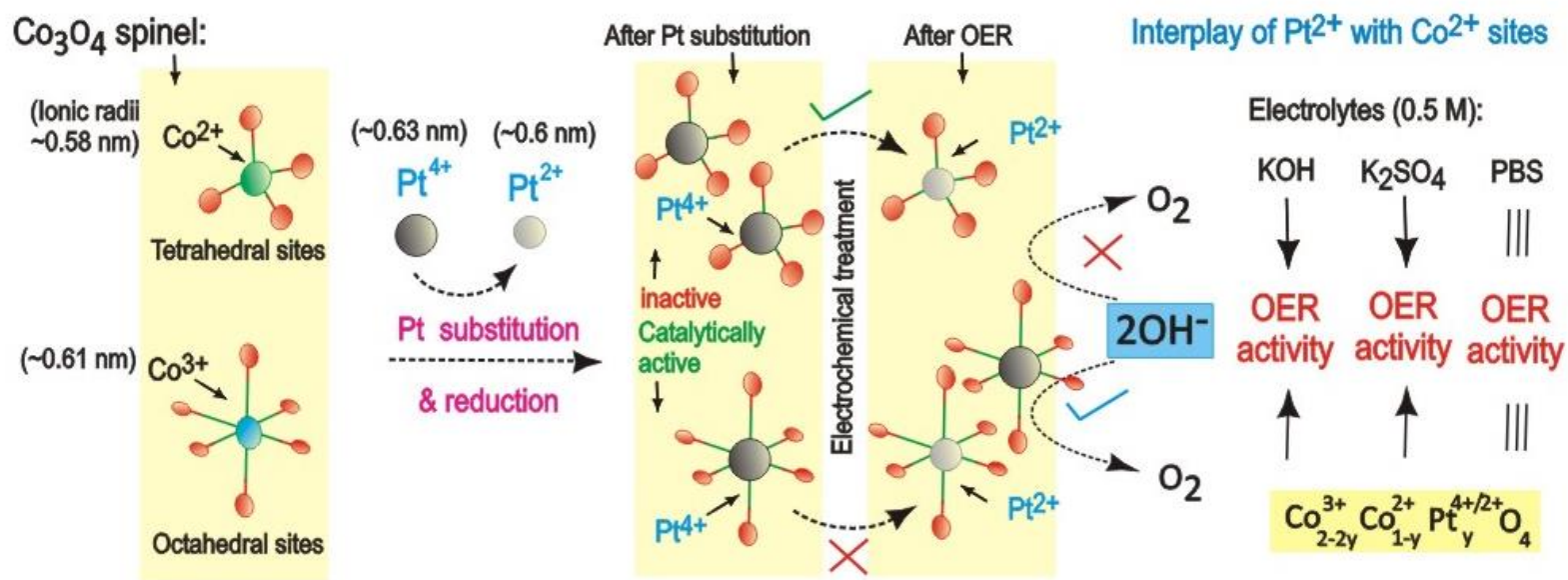

Scheme 1: Schematic representation of combustion synthesized Pt substituted $\mathrm{Co}_{3} \mathrm{O}_{4}$ and possible mechanism for the evolution of surface chemistry towards OER activity. 


\section{Figure 1}
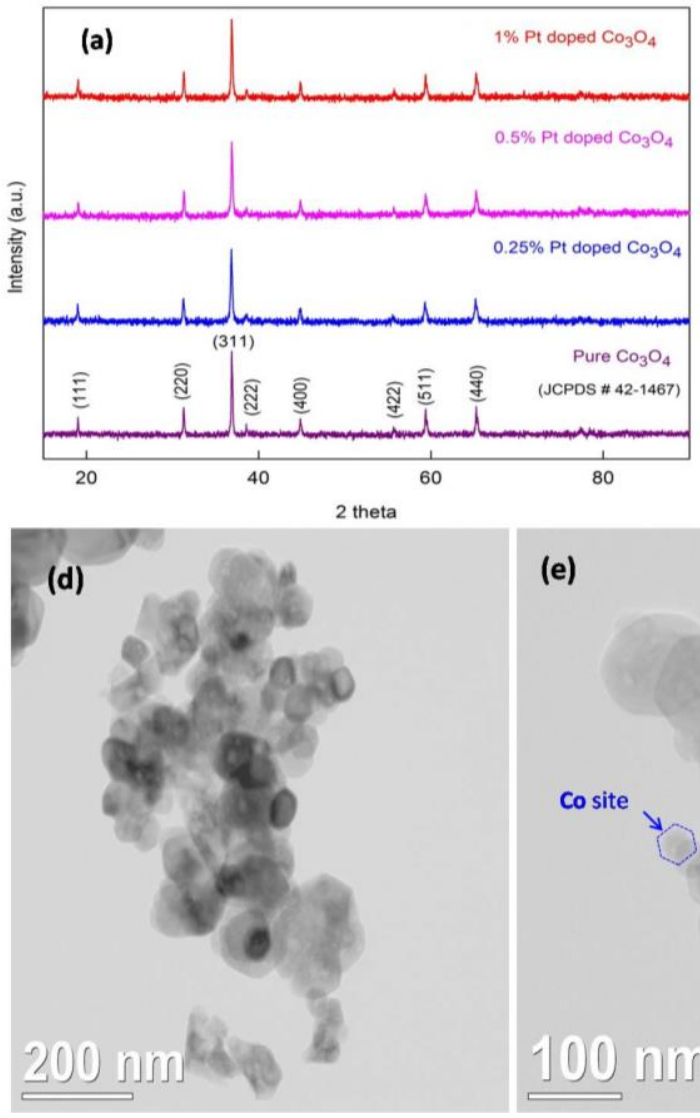
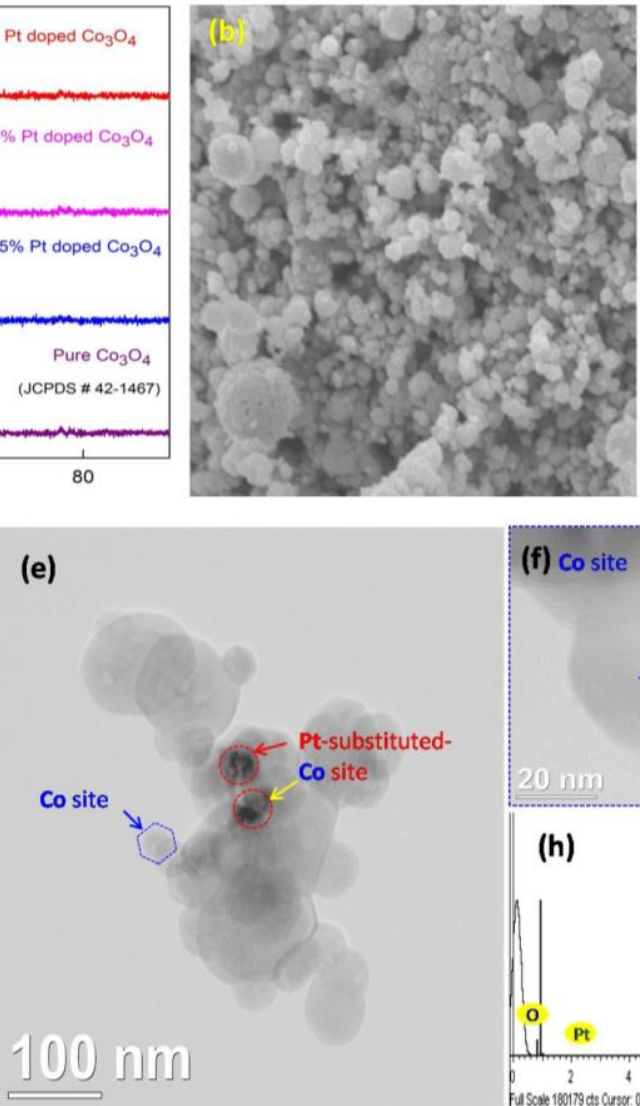
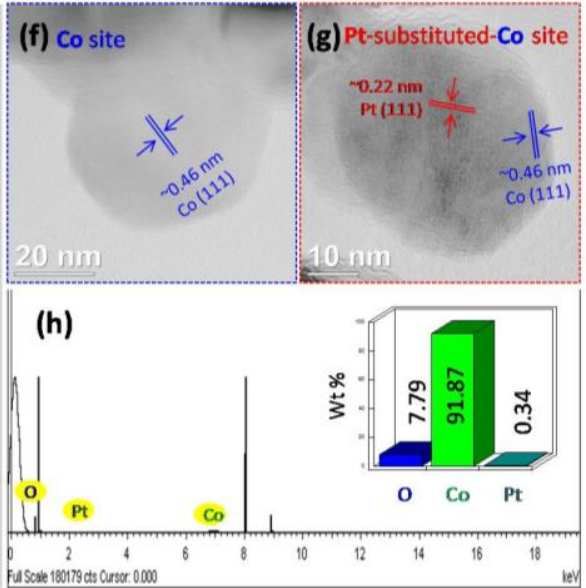

Figure 1: XRD patterns of combustion synthesized Pt substituted $\mathrm{Co}_{3} \mathrm{O}_{4}$ and pure $\mathrm{Co}_{3} \mathrm{O}_{4}$ catalysts (a). Microscope observation of the $1 \%$ Pt substituted $\mathrm{Co}_{3} \mathrm{O}_{4}$ catalyst: Low and high magnification SEM images of $1 \% \mathrm{Pt}$ substituted $\mathrm{Co}_{3} \mathrm{O}_{4}$ (b \& c), HRTEM images of $1 \% \mathrm{Pt}$ substituted $\mathrm{Co}_{3} \mathrm{O}_{4}$ and EDS spectrum with an inset of weight percentage of $\mathrm{Co}, \mathrm{O}, \mathrm{Pt}$ atoms (d-h). 


\section{Figure 2}
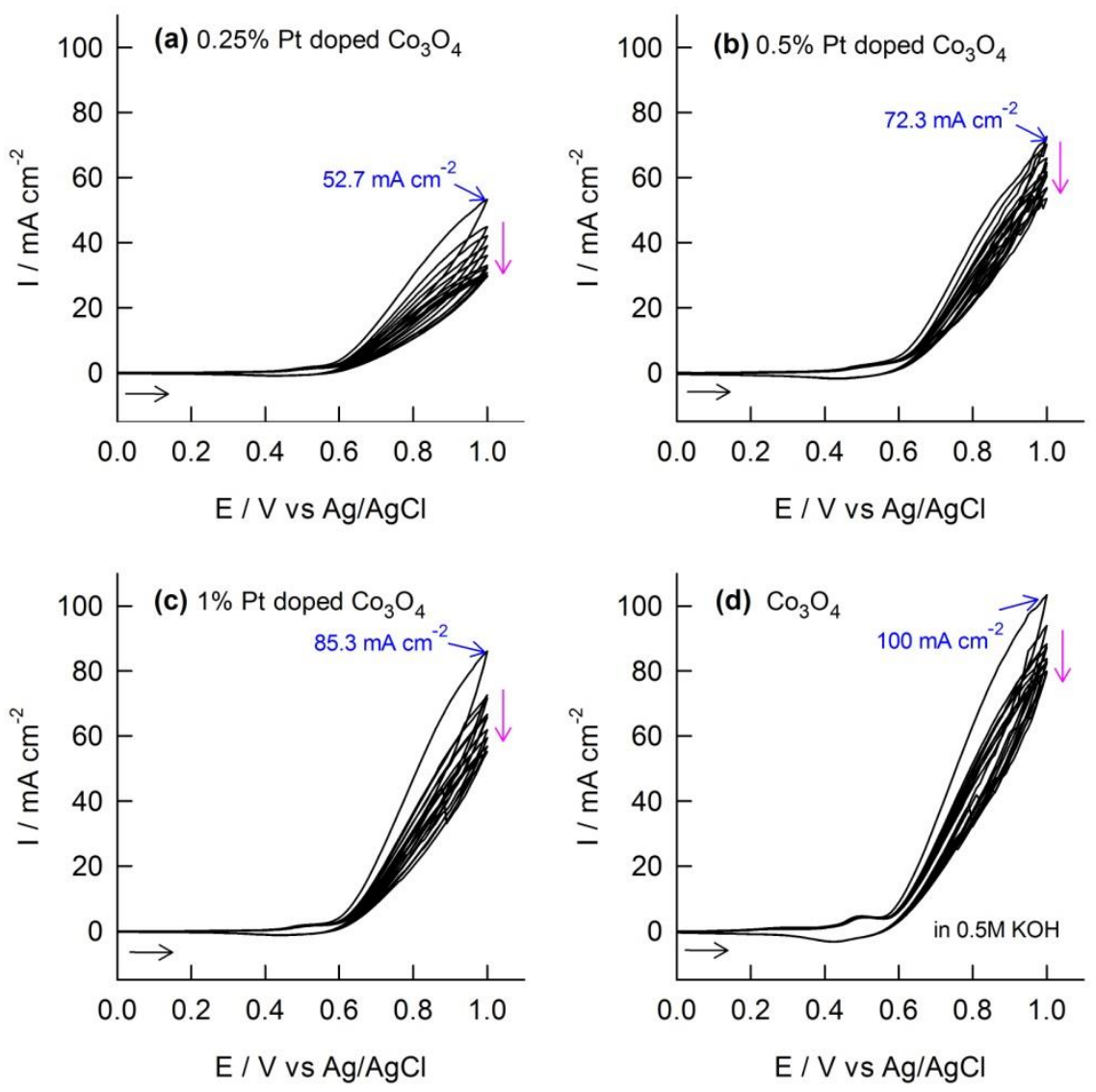

Figure 2: CV of $\mathrm{Pt}$ substituted $\mathrm{Co}_{3} \mathrm{O}_{4}$ catalyst for different doping percentage of $\mathrm{Pt}$ (a) $0.25 \%$, (b) $0.5 \%$, (c) $1 \%$, and undoped $\mathrm{Co}_{3} \mathrm{O}_{4}(\mathrm{~d})$ and at $40 \mathrm{mV} \mathrm{s}^{-1}$ of scan rate in $0.5 \mathrm{M} \mathrm{KOH}$ electrolyte. 


\section{Figure 3}
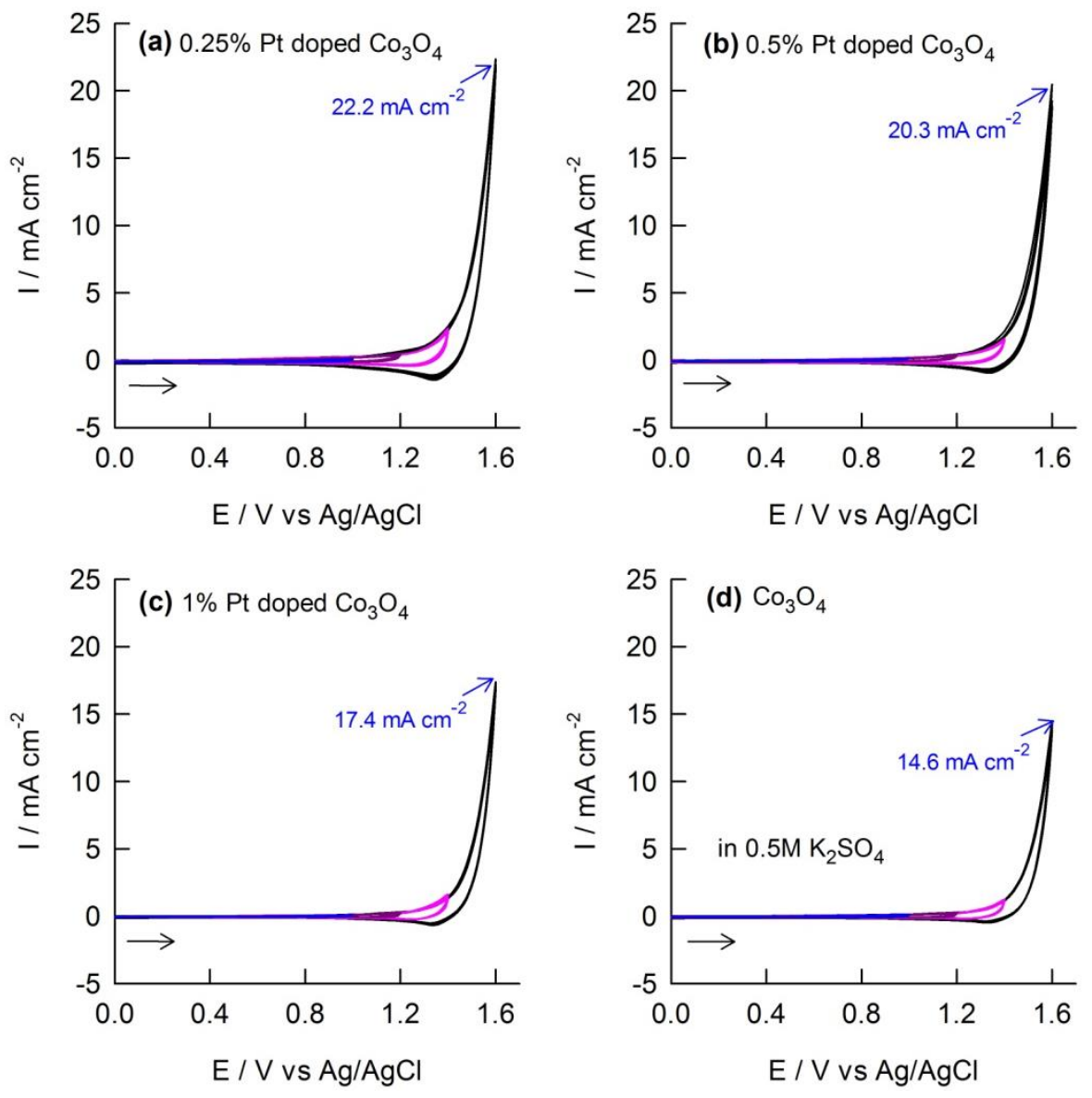

Figure 3: CV of Pt substituted $\mathrm{Co}_{3} \mathrm{O}_{4}$ catalyst for different doping percentage of $\mathrm{Pt}$ (a) $0.25 \%$, (b) $0.5 \%$, (c) $1 \%$, and undoped $\mathrm{Co}_{3} \mathrm{O}_{4}$ (d) and at $40 \mathrm{mV} \mathrm{s}^{-1}$ of scan rate in $0.5 \mathrm{M} \mathrm{K}_{2} \mathrm{SO}_{4}$ neutral electrolyte. 


\section{Figure 4}
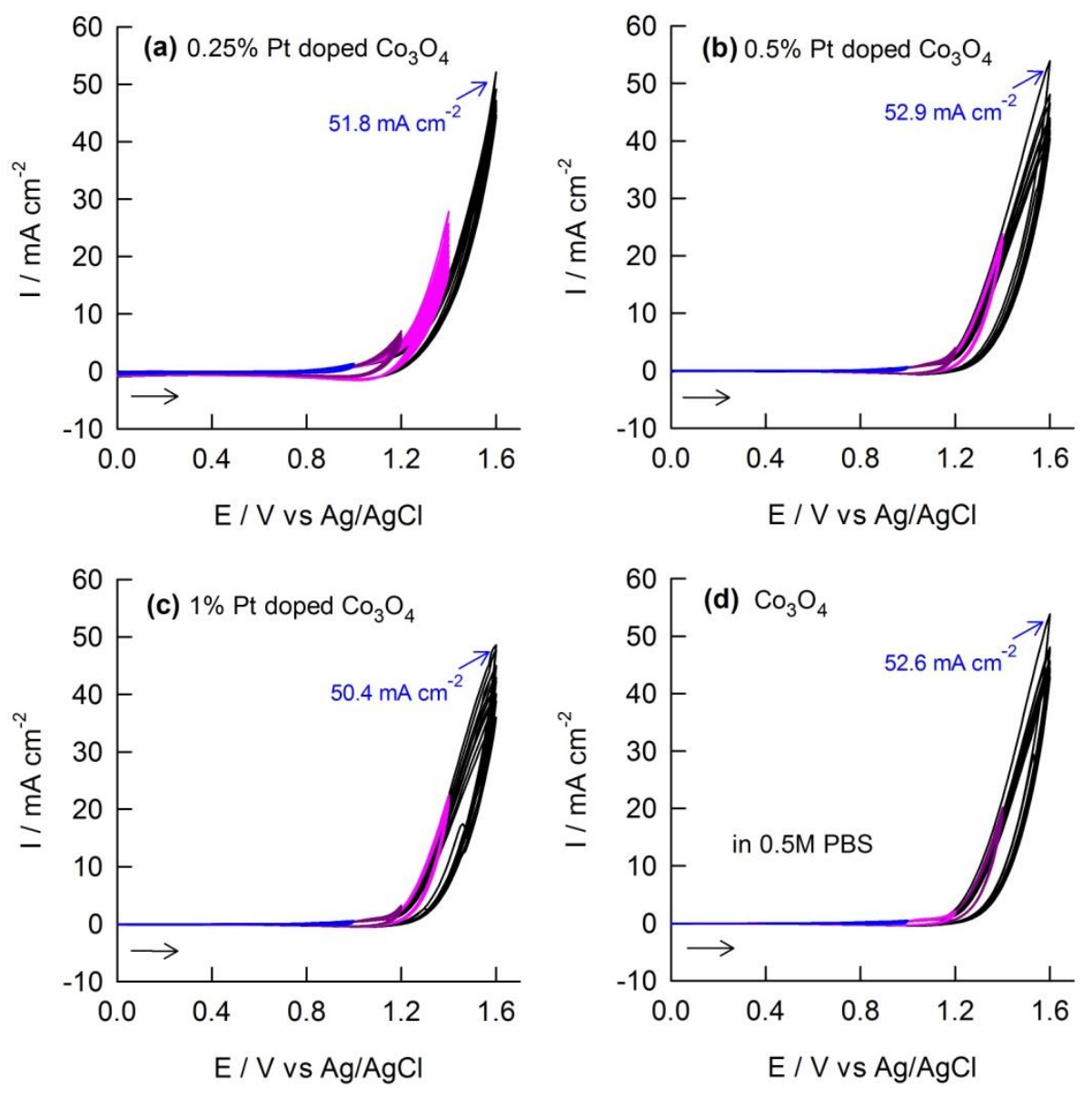

Figure 4: $\mathrm{CV}$ of $\mathrm{Pt}$ substituted $\mathrm{Co}_{3} \mathrm{O}_{4}$ catalyst for different doping percentage of $\mathrm{Pt}$ (a) $0.25 \%$, (b) $0.5 \%$, (c) $1 \%$, and undoped $\mathrm{Co}_{3} \mathrm{O}_{4}$ (d) and at $40 \mathrm{mV} \mathrm{s}^{-1}$ of scan rate in $0.5 \mathrm{M}$ PBS neutral electrolyte. 


\section{Figure 5}
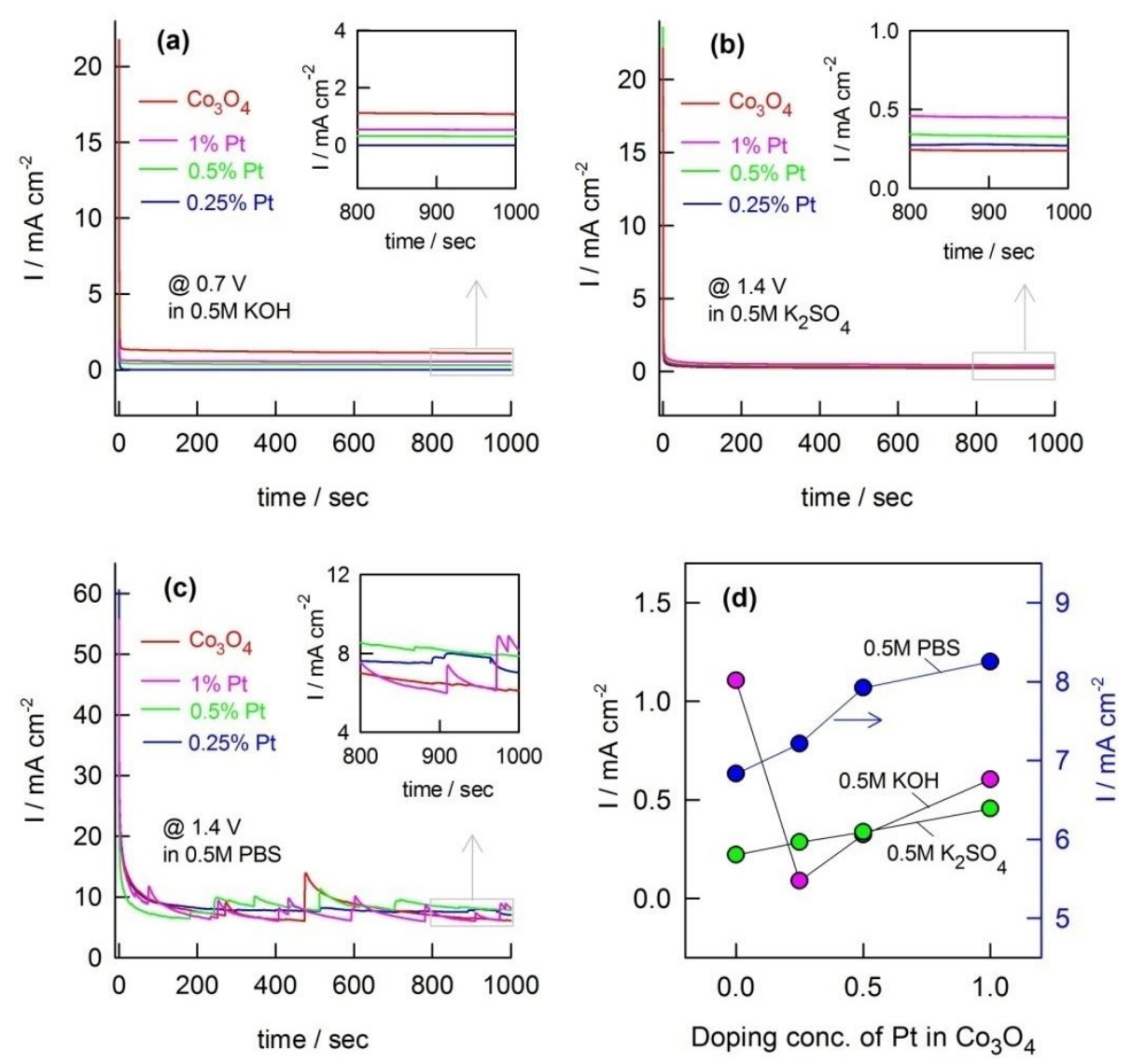

Figure 5: Chronoamperometric responses of $\mathrm{Co}_{3} \mathrm{O}_{4}$ and $\mathrm{Pt}$ substituted $\mathrm{Co}_{3} \mathrm{O}_{4}$ catalysts (a) at $0.7 \mathrm{~V}$ in $0.5 \mathrm{M} \mathrm{KOH}$ and at $1.4 \mathrm{~V}$ in $0.5 \mathrm{M} \mathrm{K}_{2} \mathrm{SO}_{4}$ (b) and at $1.4 \mathrm{~V}$ in $0.5 \mathrm{M}$ PBS (c) electrolytes along with their corresponding current density after 1000 seconds with respect to Pt doping concentration (d). 


\section{Figure 6}
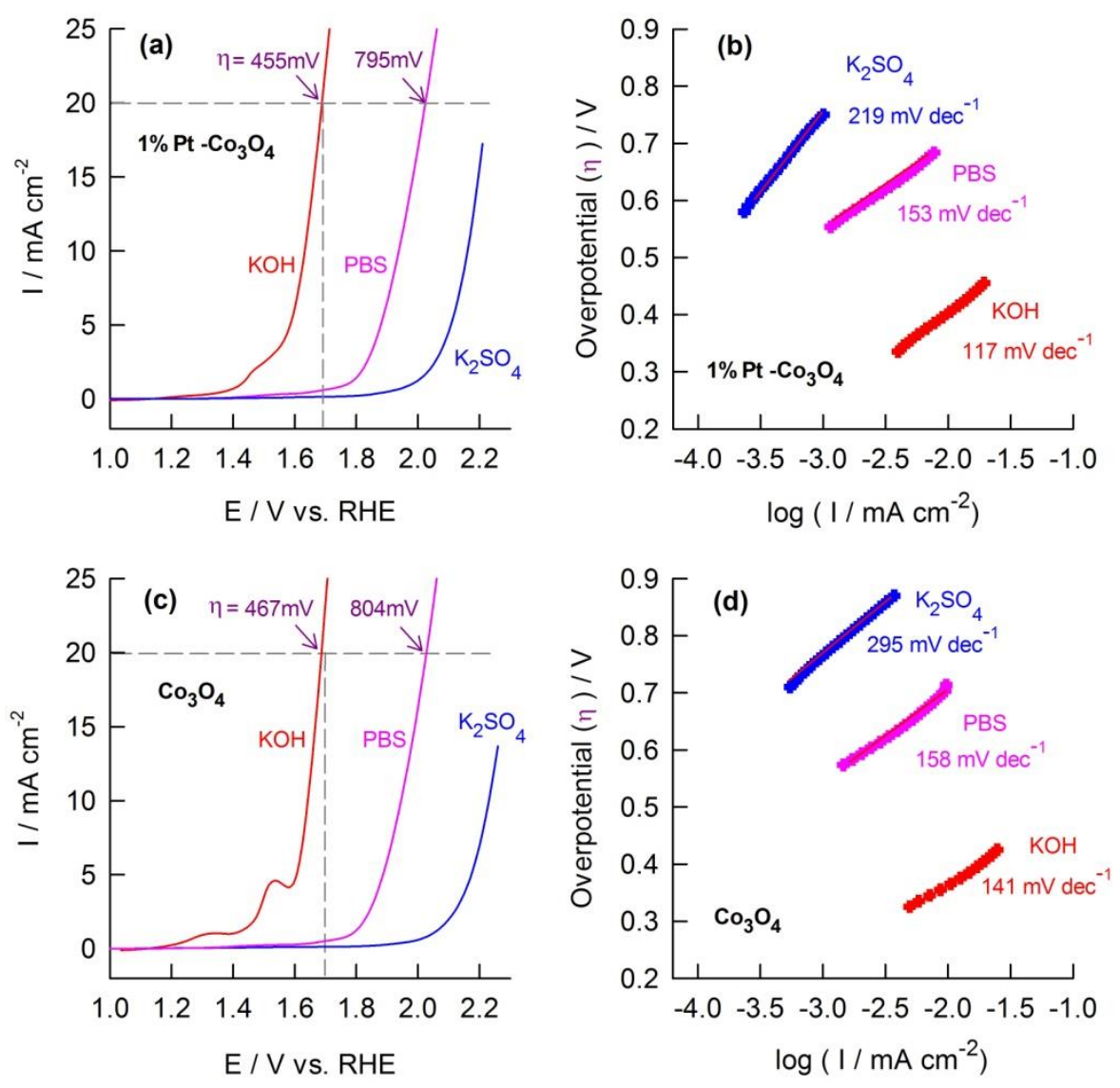

Figure 6: LSV responses of $1 \%$ Pt-substituted- $\mathrm{Co}_{3} \mathrm{O}_{4}$ (a) and undoped pure $\mathrm{Co}_{3} \mathrm{O}_{4}$ (c) at $20 \mathrm{mV} \mathrm{s}^{-1}$ of scan rate in $0.5 \mathrm{M} \mathrm{KOH}, 0.5 \mathrm{M} \mathrm{K}_{2} \mathrm{SO}_{4}$ and $0.5 \mathrm{M}$ PBS electrolyte along with their respective Tafel plot (b and d). 


\section{Figure 7}
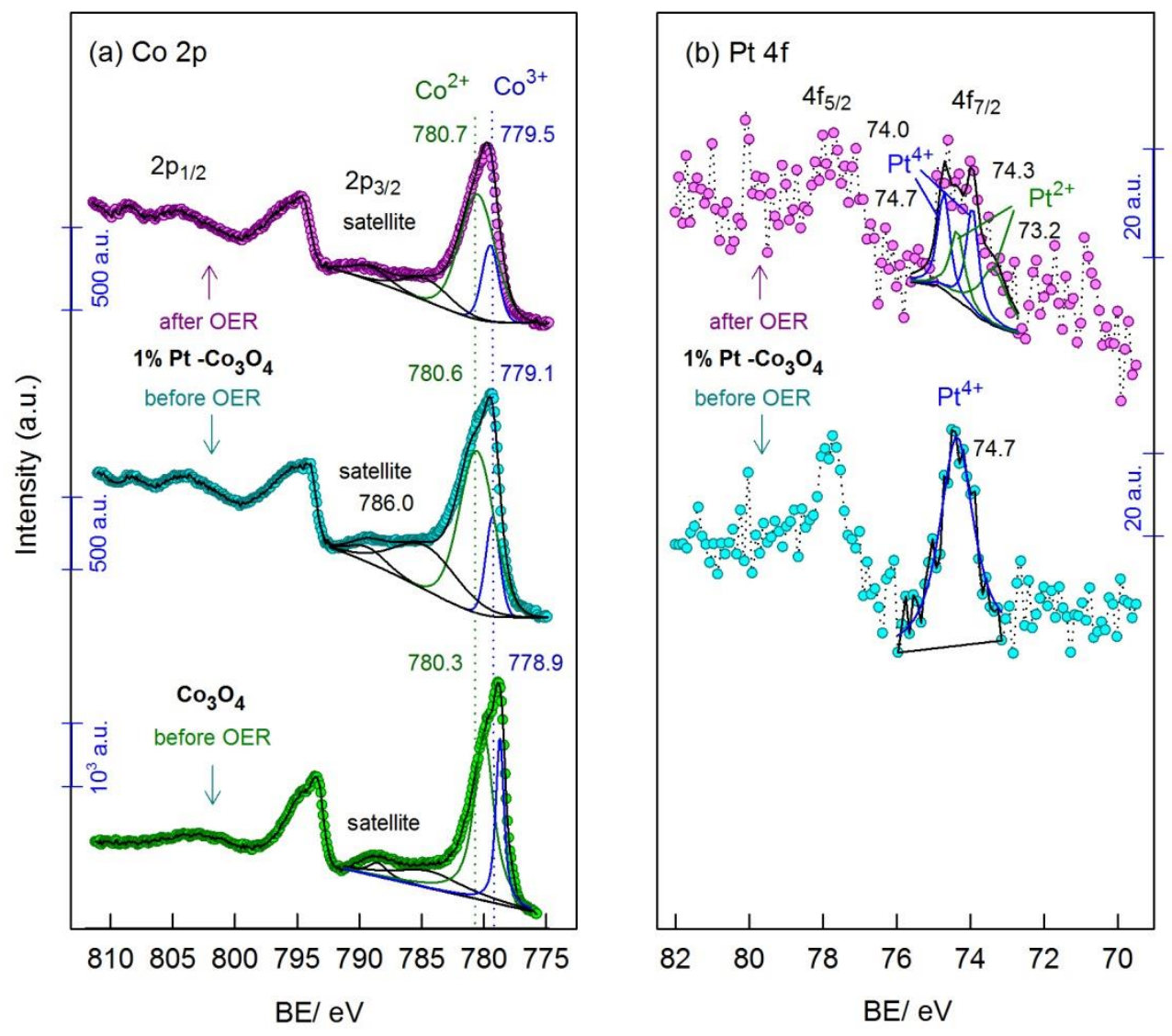

Figure 7: High resolution XPS spectra of $\mathrm{Co} 2 \mathrm{p}$ (a) of pure $\mathrm{Co}_{3} \mathrm{O}_{4}$ catalyst (before OER) and Pt $4 \mathrm{f}$ (b) region of on Pt-substituted- $\mathrm{Co}_{3} \mathrm{O}_{4}$ catalyst (before and after OER). 


\section{TOC}

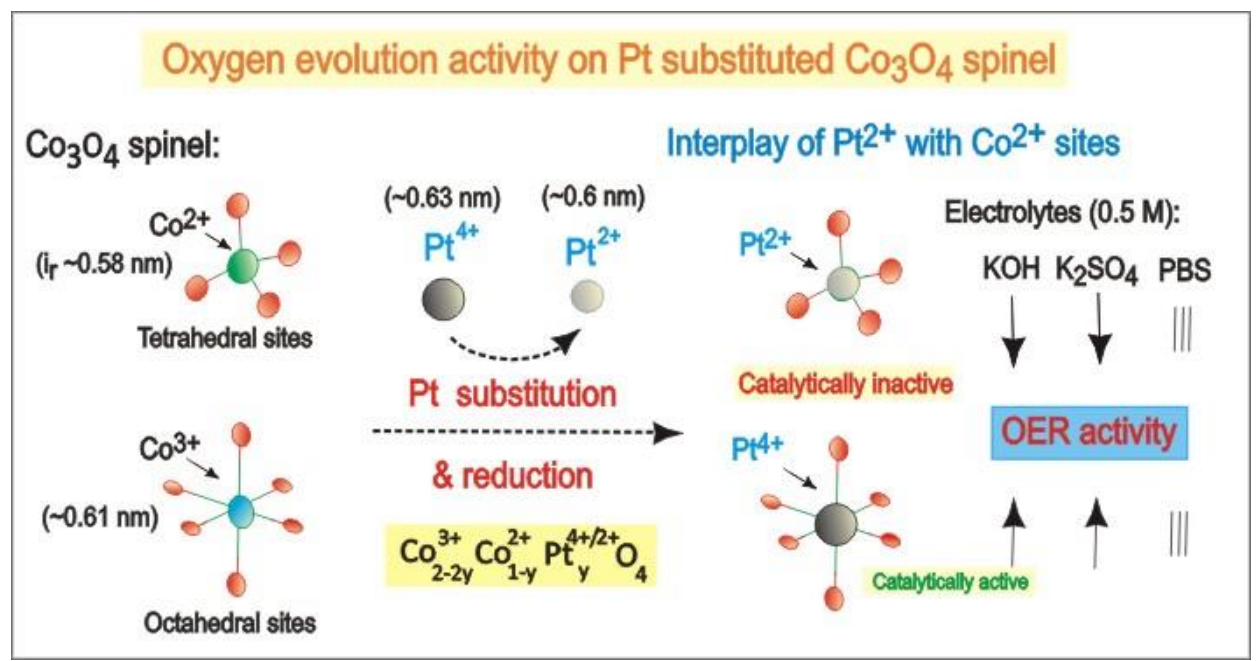

